\title{
Connective Tissue Alteration
}

National Cancer Institute

\section{Source}

National Cancer Institute. Connective Tissue Alteration. NCI Thesaurus. Code C40870.

Connective Tissue Alteration involves a qualitative change in the existing state of supporting tissue derived from mesenchyme that binds other tissues and consists of various cell types embedded in a fibrous and ground substance extracellular matrix. 